\title{
Trace metal uptake in cockles Anadara trapezium from Lake Macquarie, New South Wales
}

\author{
Peter Scanes
}

Environment Protection Authority, New South Wales, Locked Bag 1502, Bankstown, New South Wales 2200, Australia

\begin{abstract}
Trace metal contamination of waters, sediments and animals in northern Lake Macquarie has been identified as a matter of concern by regulatory authorities. Experimental procedures using the benthic bivalve Anadara trapezium (Sydney cockle) were developed to examine hypotheses relating to whether the cockle accumulated trace metals free in the water or from the sediment in which it is partially buried. Experiments were done in 1989 and 1991 to determine whether the concentration of trace metals in cockles was related to the concentration of metals in surrounding water or sediments. Pilot experiments indicated that it was possible to translocate tubs of sediments from impacted areas to unimpacted areas with no loss of trace metals from contaminated sediments and conversely with no increase in metals in uncontaminated sediments. Other experiments showed clearly that the presence of elevated levels of lead, copper and zinc in the water led to much greater levels in the cockles, irrespective of the concentration in surrounding sediments. There were no significant trends for cadmium It was concluded that the sediments in which a cockle was living had little bearing on the levels of zinc, copper and lead that were accumulated in the cockle, whereas the surrounding waters had a considerable effect.
\end{abstract}

KEY WORDS: Anadara trapezium - Bioaccumulation - Management - Power - Sediments - Trace metals

\section{INTRODUCTION}

The detection of contamination of marine and estuarine systems by industrial pollutants such as trace metals has received considerable attention (e.g. Phillips 1977, Martin 1985). Phillips (1977) recommends that biological indicators (specifically accumulators of metals) are the best indicators of trace metal pollution as they detect that portion of the contaminant load that is available to organisms. Other methods of detecting environmental contamination include analysis of water and sediments. These have been traditionally favoured (e.g. Batley 1987) but, as Phillips (1977) pointed out, they suffer from problems in interpretation of biological effects or considerable temporal and spatial variability. Biota are perceived as being able to integrate or smooth out some of the short-term variability and reflect longer-term trends. Various attempts to determine biological relevance of analyses of sediments have been attempted, mainly by extraction of metals in different solvents (Batley 1987), some of which are said to emulate the bioavailable fractions of the total load of metals (Salomons \& Forstner 1980, Batley 1987). Despite possible problems with correlating total load of metals with biological effects, contamination of sediments is often cited as an indicator of industrial contamination and potential biological impact (e.g. Phillips \& Yim 1981, Gray et al. 1988).

Underwood \& Peterson (1988) made the case that an important part of a study of pollution is that the methodology should elucidate the mechanism which is causing the observed biological effect. This is often overlooked in studies correlating biological effects and concentrations of pollutants in sediments (e.g. Brooks \& Rumsby 1965, Cain \& Luoma 1990), where it is assumed that the contamination of the sediments has led to the biological effect. This paper investigates that assumption by testing whether contaminants in the sediments or in the water column led to contamination of cockles in Lake Macquarie, New South Wales, Australia.

Lake Macquarie (Fig. 1) is a coastal lagoon which has received industrial and sewage effluent discharges 


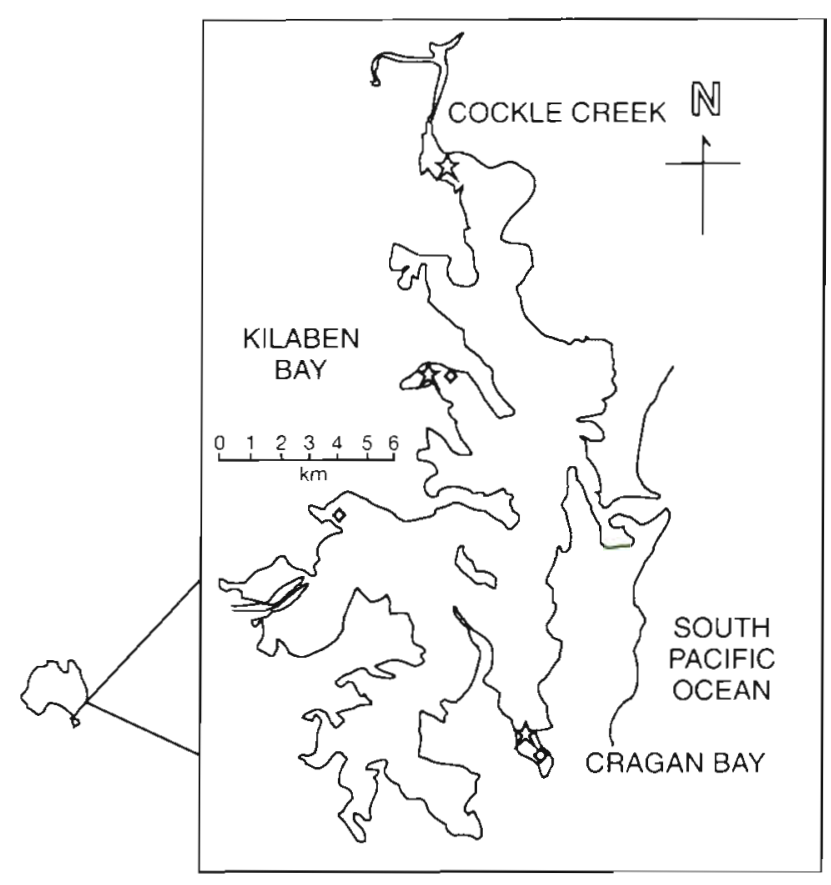

Fig. 1 Lake Macquarie (NSW, Autralia) showing position of experimental areas (is) and areas where cockles were collected $(0)$

for over 100 yr. Contamination of sediments and water by trace metals has occurred in the northern quarter of the Lake (Batley 1987). The main trace metals present above background levels in the sediments and water column were zinc, cadmium, copper and lead. The sediments were considered to have been contaminated from past and present industrial and sewage discharge into Cockle Creek, which drains into the northern end of Lake Macquarie. Batley (1987) found concentrations of total dissolved zinc, cadmium and lead in water 1 to 2 orders of magnitude greater at Cockle Creek than near to, or in areas similar to, the control sites used in the present study. Concentrations of copper appeared to be smaller at the terminal ends of bays. Concentrations of the 4 metals in sediments were an order of magnitude greater at Cockle Creek than at the control sites chosen in the present study.

A lamellibranch bivalve, the cockle Anadara trapezium (DeShayes, 1839), sampled from northern parts of the lake, has been shown to accumulate some trace metals to levels greater than those recommended for human consumption. The ability of bivalves to accumulate trace metals has been well documented (Phillips 1977).

Field experimentation was judged to be the most effective means of attempting to identify the source of contamination (Connell 1961, Dayton 1971, Underwood 1986, 1990). Experiments are, however, only able to identify causal factors if the design is unconfounded (Green 1979, Hurlbert 1984, Underwood 1986, 1989, 1990). The field experiments in the present study utilised control treatments for all manipulations in order to provide unconfounded conclusions.

This study addressed 3 linked null hypotheses - that there are expected to be no differences in the concentrations of trace metals in cockles exposed to water with elevated concentrations of metals compared to cockles in unaffected areas; that there are expected to be no differences in the concentrations of trace metals in cockles exposed to sediment with elevated concentrations of metals compared to cockles in unaffected areas; and that there are expected to be no differences in the concentrations of trace metals in cockles exposed to both water with elevated concentrations of metals and sediments with elevated concentrations of metals compared to those in unaffected areas. The temporal consistency of patterns indicated by the experiment was examined by repeating the whole series of experiments.

The results of the tests of these hypotheses will enable determination of whether cockles take up metals which were free in the water or bound in the sediment, and thus indicate the best future actions to reduce metal contamination of cockles in Lake Macquarie.

\section{METHODS}

In order to provide orthogonal comparisons of contaminated and uncontaminated sediments and water, reciprocal translocations of sediments between impacted areas and unimpacted areas were made. Batley (1987) showed that concentrations of trace metals in water and sediments in Lake Macquarie were elevated in the vicinity of Cockle Creek, and it was from this area that contaminated sediments were collected and treatments requiring water with elevated levels of trace metals were set up. The unimpacted areas used for the experiments, Kilaben Bay and Crangan Bay (Fig. 1), were also chosen on the basis of data from Batley (1987).

The experimental design used (Table 1) includes the use of 2 control (unimpacted) locations, and control treatments for the effects of disturbance of sediments and translocation between impact and treatment locations and between control locations. Three places were chosen in $2 \mathrm{~m}$ water depth within each location. One replicate of each treatment (undisturbed control, a disturbance control and 2 translocations; Table 1) was put at each place.

Undisturbed control plots were areas of $50 \times 50 \mathrm{~cm}$ with undisturbed sediments, marked with wooden stakes at the corners. Sediments to be translocated or 
Table 1. Design for trace metal study. Each treatment at each location was replicated 3 times, and there were 5 cockles analysed per treatment $(\mathrm{n}=5)$. S: sediment; $\mathrm{W}$ : water; $t_{1}$ - indicate presence or absence of great concentrations of trace metals

\begin{tabular}{|lcccc|}
\hline Location & $\begin{array}{c}\text { A } \\
\text { Untouch. } \\
\text { control }\end{array}$ & $\begin{array}{c}\text { B } \\
\text { Disturb. } \\
\text { control }\end{array}$ & $\begin{array}{c}\text { C } \\
\text { Translocat. }\end{array}$ & $\begin{array}{c}\text { D } \\
\text { Translocat. }\end{array}$ \\
\hline 1. Cockle & $+\mathrm{S}$ & $+\mathrm{S}$ & $-\mathrm{S}$ & $-\mathrm{S}$ \\
Creek & $+\mathrm{W}$ & $+\mathrm{W}$ & $+\mathrm{W}$ & $+\mathrm{W}$ \\
& & from: & Location 2 & Location 3 \\
2. Kilaben & $-\mathrm{S}$ & $-\mathrm{S}$ & $+\mathrm{S}$ & $-\mathrm{S}$ \\
$\begin{array}{l}\text { Bay } \\
\text { (control) }\end{array}$ & $-\mathrm{W}$ & $-\mathrm{W}$ & $-\mathrm{W}$ & $-\mathrm{W}$ \\
3. Crangan & $-\mathrm{S}$ & $-\mathrm{S}$ & $+\mathrm{S}$ & $-\mathrm{S}$ \\
Bay & $-\mathrm{W}$ & $-\mathrm{W}$ & $-\mathrm{W}$ & $-\mathrm{W}$ \\
(control) & & from: & Location 1 & Location 2 \\
\hline
\end{tabular}

disturbed were placed in plastic tubs $(350 \times 600 \times$ $200 \mathrm{~mm}$ deep, volume ca 42 l) by divers, brought to the surface and placed in a boat. The tubs were then either replaced as disturbance controls or moved to another location according to the design in Table 1 . Tubs were partially buried so that the top of the tubs protruded about $50 \mathrm{~mm}$ above the lake floor. This procedure was designed to reduce drift of sediment into or out of the tubs.

To test the efficacy of this procedure for translocating sediments, a pilot study of 6 wk duration (in 1989) compared the concentrations of metals in sediments before disturbance and 6 wk after being placed in plastic tubs and translocated. The experiment used one impact (Cockle Creek) and one control (Crangan Bay) location. Three replicate samples of sediment were taken from each tub at the beginning and end of study. The pilot study was based on the assumption that any loss of metals from the sediments would occur mainly during the disturbance and moving of the sediment.

Anadara trapezium (Sydney cockle) is a common estuarine bivalve about $40 \mathrm{~mm}$ long, often found in association with beds of the seagrass Zostera capricornia Ascherson. It is usually found embedded in sediment with about $25 \%$ of the valves protruding. It has very limited (if any) mobility. Cockles used in all tests were collected from a number of unimpacted areas in the southern and central parts of the lake (Fig. 1) and combined into a common pool. From this pool of cockles, 15 were selected at random and placed by divers into the sediment in each treatment, in their natural orientation, in September 1989 and 1991. All treatments (including untouched controls) were enclosed in plastic mesh (15 $\mathrm{mm}$ mesh), as experience had shown that cockles were a favoured item of benthic predators in the Lake.
The experiment was terminated in November of each year and all cockles were removed from each treatment. Cockles were immediately placed in plastic bags and frozen. Mortality and loss had reduced the number of cockles in some treatments, so 5 cockles were randomly selected for analysis from those collected for each treatment.

The tissue concentrations of zinc and cadmium were determined on undried samples by flame atomic absorption spectroscopy (flame AAS) after digestion in nitric acid and hydrogen peroxide. Copper and lead were determined in the organic phase by flame AAS after adding sodium iodide and extracting the $\mathrm{Pb}$ and $\mathrm{Cu}$ iodide complexes in $n$-butyl acetate containing $3 \%$ tri- $n$-octylamine. Concentrations were reported as $\mu \mathrm{g} \mathrm{g}^{-1}$ wet weight.

Data were analysed by analysis of variance after first checking for homogeneity of variance, and transforming data if necessary (Underwood 1981). Concentrations of metals in 5 replicate individual cockles from each treatment at each of the 3 replicate places at each location were pooled for statistical analyses (i.e. $n=15$ ).

Post-hoc power analyses (Underwood 1981) were done on the data to determine the power of non-significant tests. The alternative hypothesis being tested was that of a 20 or $40 \%$ difference in means between experimental and pooled control 'treatments' at each time. In the absence of any data from the literature which might indicate what is an 'important' or biologically 'significant' change in concentrations of metals, I have selected differences which indicate power for changes that were much smaller than those found for the significant analyses of the effects of 'location' (where differences of 50 to $700 \%$ occurred). This rationale aims to demonstrate that both main factors had similar power to detect differences.

\section{RESULTS}

\section{Pilot study - sediments}

Concentrations of zinc, cadmium, lead and copper were all an order of magnitude larger in Cockle Creek (impacted) sediments than Crangan Bay (unimpacted) sediments (Fig. 2). There were significant differences from start to finish (Date) for all metals (Table 2) and significant Date $\times$ Place interactions (Fig. 2). The interactions resulted from significant changes in concentrations from the beginning to the end of the experiment at Cockle Creek, but not at Crangan Bay. There was also a significant Date $\times$ Treatment interaction for copper and lead. This is a result of different sediment concentrations in the 3 treatments from Cockle Creek at the start of the experiment, but similar levels at the finish. 


\section{Zinc}
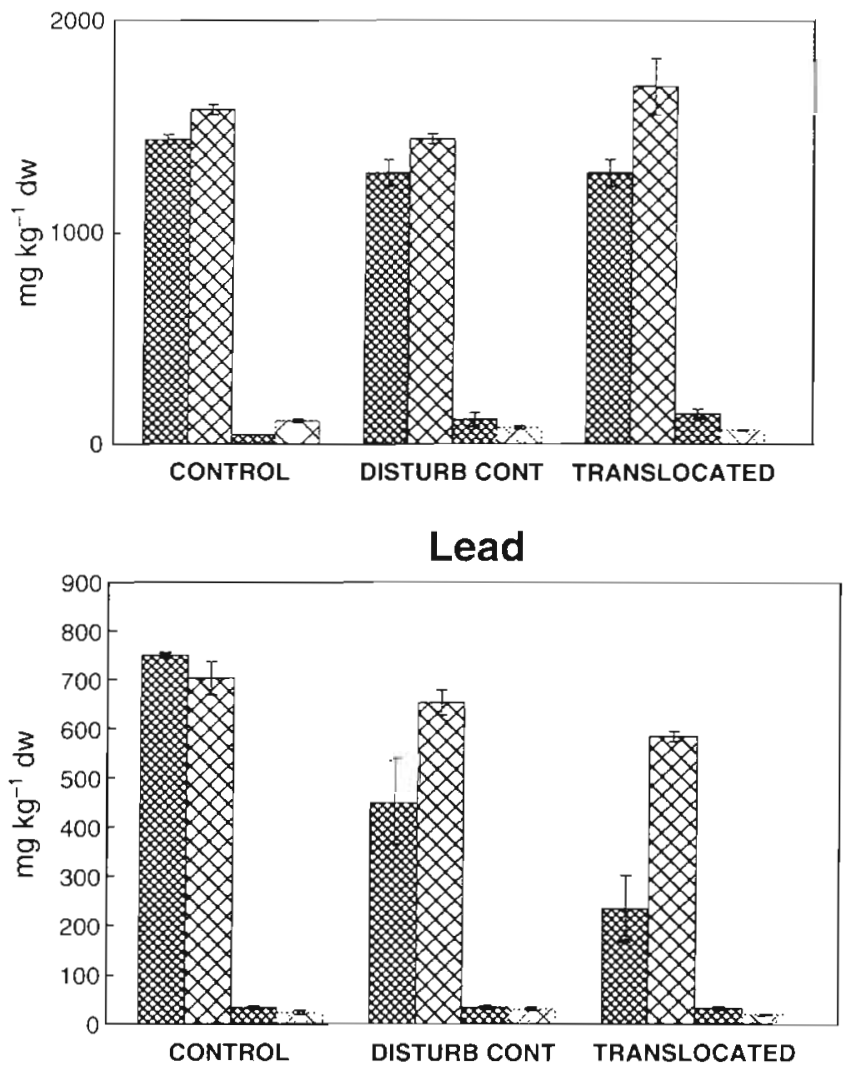

Cadmium
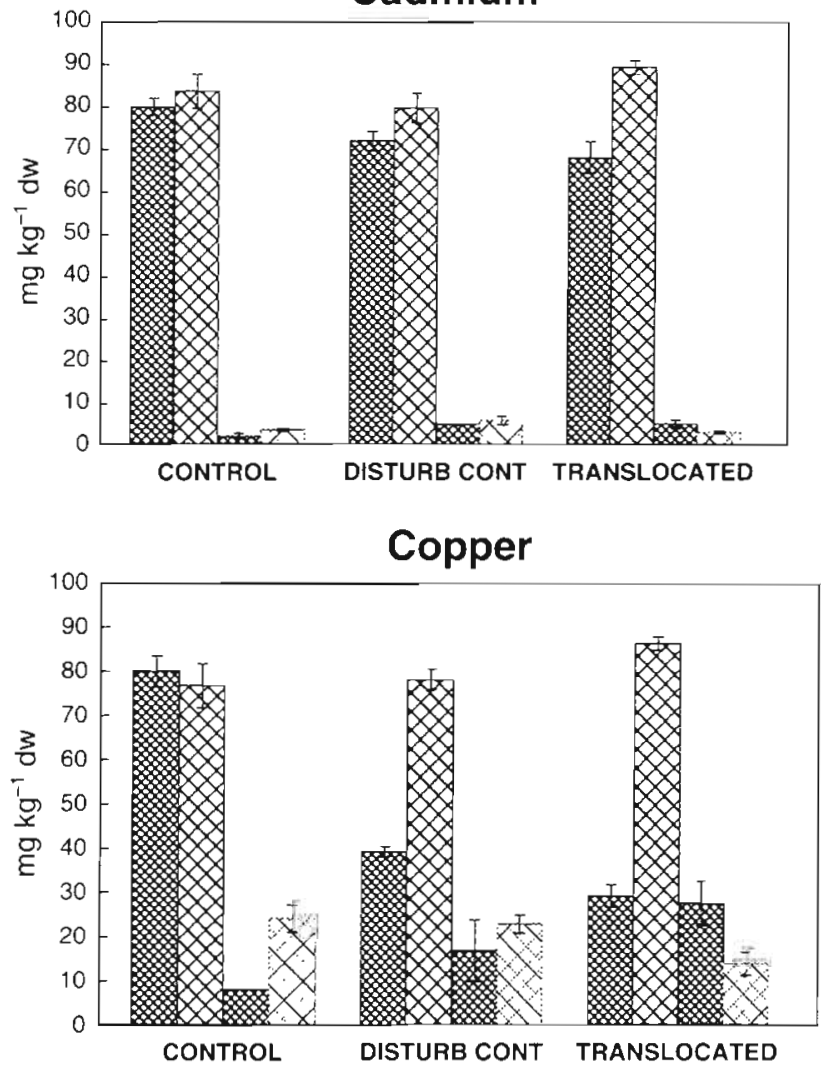

Fig. 2. Comparison of mean ( $\pm 1 \mathrm{SE}$ ) concentrations of trace metals in sediments before and after experimental manipulations (pilot study). Within each group of 4 bars the 2 bars on the left are data for Cockle Creek (affected) sediments, and the 2 on the right are Crangan Bay (unaffected) sediments. 'Control' treatments are untouched prior to collection of sediments, 'disturb control' treatments have been dug up, placed in a tub and put back in the same hole, 'translocated' have been moved between the 2 sites. Closely hatched bars are data from the start of the experiment, widely hatched bars are data from the end

The significant facts to note are that sediment concentrations did not fall over time, but actually seemed to increase in those instances where they changed signifi-

Table 2. Summaries of results of analyses of variance comparing concentrations of trace metals in sediments after disturbance - pilot study. r: random factor with respect to the model; $f$ : fixed factor with respect to the model.

\begin{tabular}{|c|c|c|c|c|c|}
\hline Source & Test df & Zinc $^{d}$ & Cadmium & Lead $^{d}$ & Copper \\
\hline Date & 1,24 & $\cdot$ & $\cdots$ & $\cdots$ & $\cdots$ \\
\hline Location & 1,1 & - & $\cdot$ & ns & ns \\
\hline $\mathrm{D} \times \mathrm{L}$ & 1,24 & $\cdots$ & $\cdots$ & $\cdots$ & $\cdots$ \\
\hline Treatment & 2,2 & ns & ns & ns & ns \\
\hline $\mathrm{D} \times \mathrm{T}$ & 2,24 & ns & ns & • & . \\
\hline $\mathrm{L} \times \mathrm{T}$ & 2,2 & ns & ns & ns & ns \\
\hline $\mathrm{D} \times \mathrm{L} \times \mathrm{T}$ & 2,24 & $\cdots$ & $\cdot$ & $\cdot$ & $\cdots$ \\
\hline \multicolumn{6}{|c|}{$\begin{array}{l}{ }^{a} \text { Data transformed to square root }(x+1) \text {; all variances } \\
\text { stabilised (i.e. Cochrans test, } p>0.05 \text { ) }\end{array}$} \\
\hline \multicolumn{6}{|c|}{$\begin{array}{l}\text { - Significant differences at } p<0.05 \\
\cdots \text { Significant differences at } p<0.001\end{array}$} \\
\hline
\end{tabular}

cantly. There was also no indication that translocating sediments caused any greater changes than disturbing sediments and that the changes all seemed to be confined to the impacted Cockle Creek sediments. There was no indication that translocating contaminated sediments to an unimpacted area led to a reduction in the level of contamination of those sediments, or conversely, that moving uncontaminated sediments to an impacted area resuited in an increase in the metal concentration in the sediments.

\section{Main study - cockles \\ Effect of disturbance}

The first comparison made was between specimens from disturbed and undisturbed controls. This comparison was required to confirm the validity of generalising the results obtained from specimens in tubs to those not in tubs. There was no significant difference 

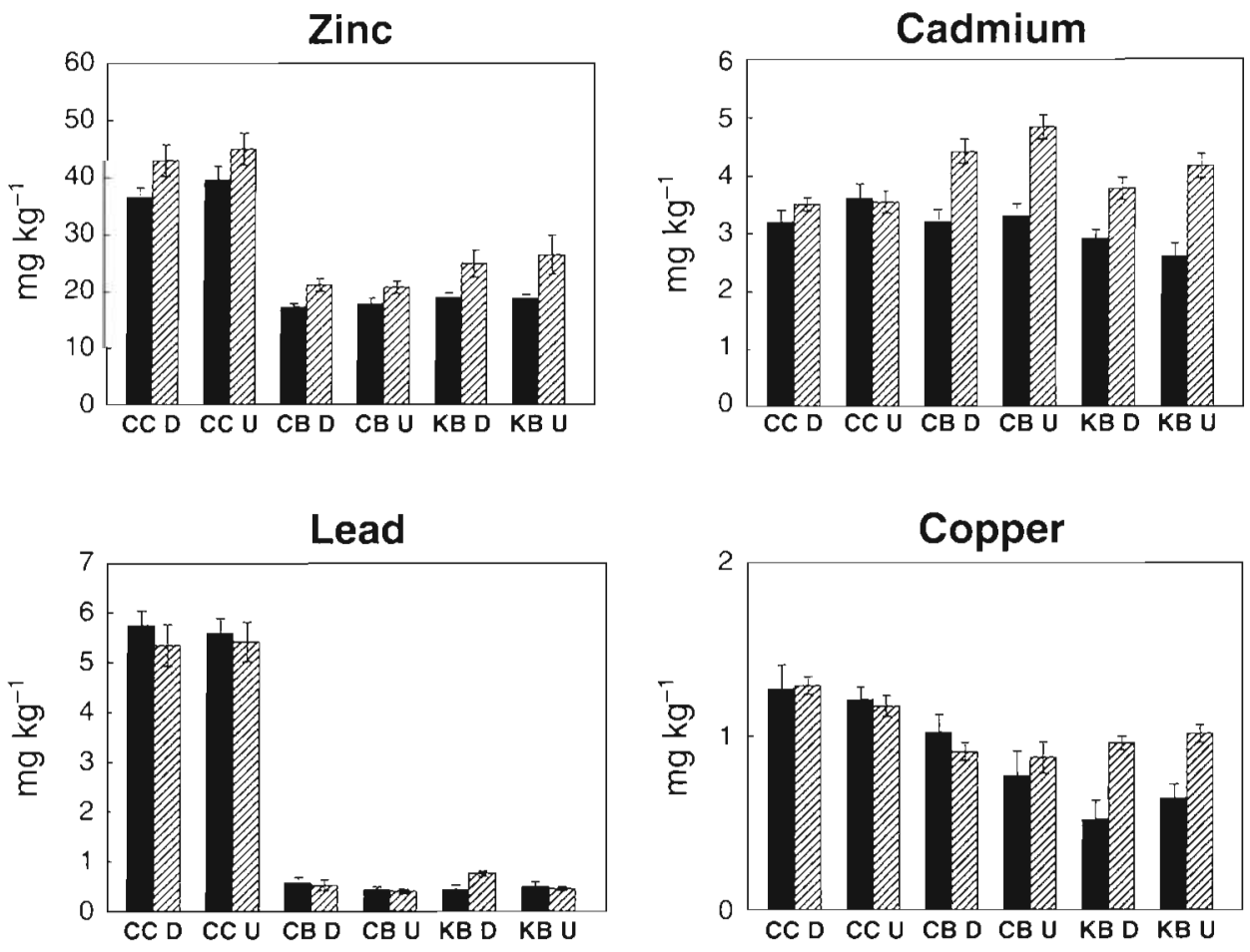

Fig. 3. Anadara trapezium. Comparison of mean ( $\pm 1 \mathrm{SE}$ ) concentrations of metals in cockles from disturbed $(D)$ and undisturbed controls (U), main study. CC: Cockle Creek; CB: Crangan Bay; KB: Kilaben Bay. Solid bars: data from 1989; hatched bars: data from 1991

between metal concentrations in the tissue of cockles in disturbed and undisturbed controls ('Treatments'; Table 3, Fig. 3). There were significant differences between locations (i.e. concentration of metals in the water) for zinc, lead and copper, with Cockle Creek samples having significantly greater tissue loads (SNK tests, $p<0.05)$. Interactions between date and location for cadmium and copper were caused by greater concentrations at control locations in 1991. These results indicated that it was appropriate to use the disturbed controls to compare with the various translocations.

\section{Effect of water vs sediment}

An analysis of the effects of the treatments indicated that there were no significant differences attributable to the concentration of metals in the sediments ('Treatments'; Table 4). There were, however, significant differences in the tissue loads of lead, zinc and copper (Cockle Creek $>$ Kilaben $=$ Crangan; SNK tests, $\mathrm{p}<0.05$ ) attributable to the concentration of metals in the water column (Fig. 4, 'Location' Table 4). There was no significant difference in the tissue concentrations of cadmium between treatments and the differences among locations did not seem to be related to known patterns of concentrations of cadmium in the water (Fig. 4, Table 4).
In addition, analyses of the concentrations of zinc, lead and copper indicated significant interactions between date and location and treatment and location.

These are always complex to explain in full. Here, they are presented graphically. For example, Fig. 4A(ii) describes the date by location interaction for zinc. The asterisks above the first 2 pairs of bars indi-

Table 3. Summaries of results of analyses of variance comparing concentrations of trace metals in experimental cockles from disturbed and undisturbed controls - main study. r: random factor with respect to the model; f: fixed factor with respect to the model.

\begin{tabular}{|c|c|c|c|c|c|c|}
\hline Source & & Test df & Zinc $^{\mathrm{a}}$ & Cadmium $^{a}$ & Lead $^{b}$ & Copper $^{b}$ \\
\hline Date & f & 1,12 & ns & ns & ns & ns \\
\hline Location & $\mathrm{r}$ & 2,12 & $\cdots$ & ns & $\cdots$ & $\cdots$ \\
\hline$D \times L$ & & 2,12 & ns & $\cdot$ & ns & $\cdot$ \\
\hline Treatment & & 1,4 & ns & ns & ns & ns \\
\hline $\mathrm{D} \times \mathrm{T}$ & & 1,12 & ns & ns & ns & ns \\
\hline $\mathrm{L} \times \mathrm{T}$ & & 2,12 & ns & ns & ns & ns \\
\hline $\mathrm{D} \times \mathrm{L} \times \mathrm{T}$ & & 2,12 & ns & ns & ns & ns \\
\hline \multicolumn{7}{|c|}{$\begin{array}{l}\text { 'Data transformed to } \log (x+1) \text {; } \\
\text { 'Data transformed to square root }(x+1) \text {; all variances } \\
\text { stabilised (i.e. Cochrans test, } p>0.05)\end{array}$} \\
\hline \multicolumn{7}{|c|}{ - Significant differences at $p<0.05$} \\
\hline
\end{tabular}



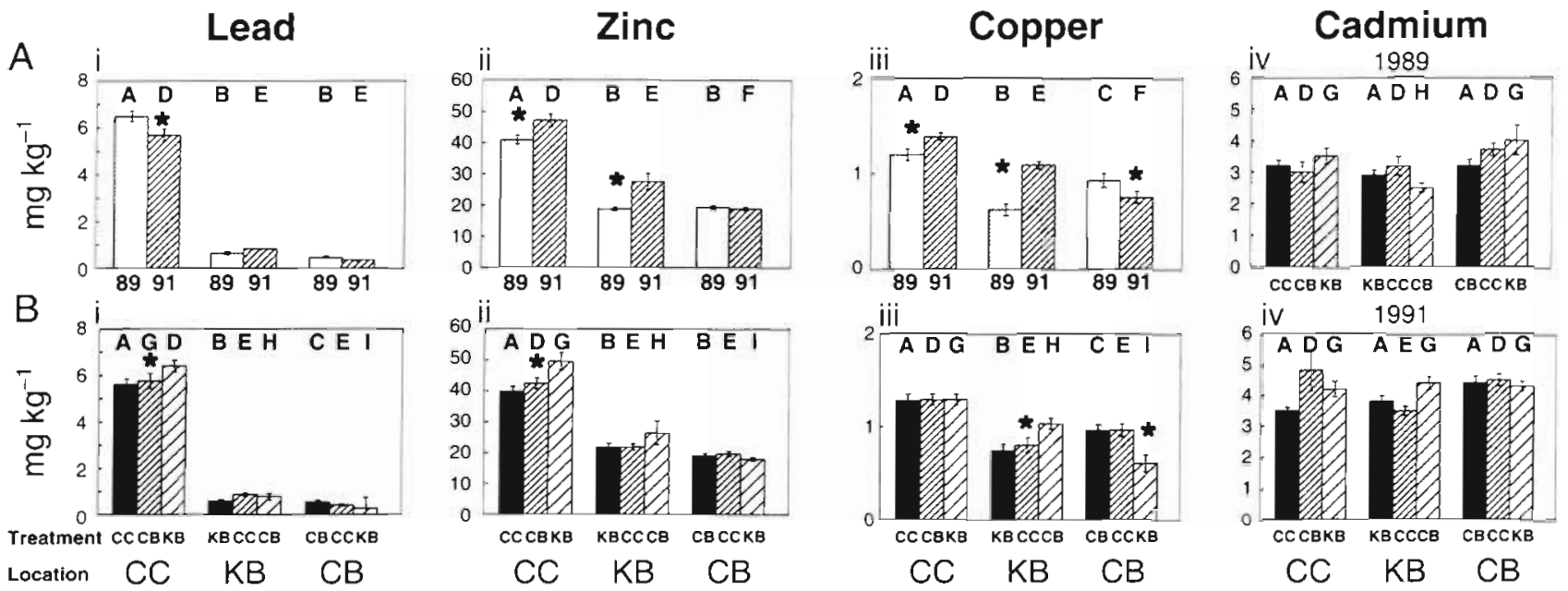

Fig. 4. Anadara trapezium. Comparison of mean ( $\pm 1 \mathrm{SE}$ ) trace metal concentrations in cockles. 'Treatment' on the $x$-axis indicates the source of the sediment in which the cockles were placed. 'Location' on the $x$-axis indicates the location at which the treatments were placed. CC: Cockle Creek (contaminated water and sediments); KB: Kilaben Bay; CB: Crangan Bay (uncontaminated water and sediments). Data in $\mathrm{A}(\mathrm{i}-\mathrm{iii})$ are treatments pooled at a location $(\mathrm{n}=45)$; $\mathrm{B}(\mathrm{i}-\mathrm{iii})$ are times pooled for each treatment $(n=30) ; A(i v)$ and $B(i v)$ are each treatment at each location and time $(n=15)$. ' Significant differences among time of sampling or treatments, i.e. within a group on the graph. Significant differences among locations for a time or treatment are shown by different letters above the bars

cate significant differences between concentrations in 1989 and 1991 at Cockle Creek and Kilaben Bay. The letters above the bars with similar shading (i.e. those from the same year) indicate that in 1989 concentrations in cockles from Cockle Creek were significantly greater than in those from Kilaben and Crangan Bays. However, in 1991, cockles from Cockle Creek were significantly more contaminated than those from Kilaben Bay, which were in turn significantly different from Crangan Bay.

The data in Fig. 4A(i-iii) show that, whilst there was temporal inconsistency in the results for any particular

Table 4. Summary of analyses of variance comparing concentrations of trace metals in experimental cockles from all treatments - main study. r: random factor with respect to the model $_{i}$ f: fixed factor with respect to the model

\begin{tabular}{|c|c|c|c|c|c|c|}
\hline Source & & Test df & $\operatorname{Zinc}^{a}$ & Cadmium $^{\mathrm{a}}$ & Lead $^{\mathrm{b}}$ & Copper ${ }^{b}$ \\
\hline Date & $\mathrm{f}$ & 1,2 & ns & $\cdot$ & ns & ns \\
\hline Location & r & 2,252 & $\cdots$ & $\cdots$ & $\cdots$ & $\cdots$ \\
\hline $\mathrm{D} \times \mathrm{L}$ & & 2,252 & • & ns & $\cdot$ & $\cdots$ \\
\hline Treatment & & 1,4 & $\mathrm{~ns}$ & ns & ns & ns \\
\hline$D \times T$ & & 1,4 & ns & ns & ns & ns \\
\hline $\mathrm{L} \times \mathrm{T}$ & & 4,252 & - & ns & - & $\cdots$ \\
\hline $\mathrm{D} \times \mathrm{L} \times \mathrm{T}$ & & 4,252 & ns & $\cdots$ & ns & ns \\
\hline \multicolumn{7}{|c|}{$\begin{array}{l}\text { a Data transformed to } \log (x+1) \text {; } \\
\text { bData transformed to square } \operatorname{root}(x+1)_{;} \text {all variances } \\
\text { stabilised (i.e. Cochrans test, } p>0.05)\end{array}$} \\
\hline \multicolumn{7}{|c|}{$\begin{array}{c}\text { - Significant differences at } p<0.05 \\
\cdots \text { Significant differences at } p<0.001\end{array}$} \\
\hline
\end{tabular}

location, concentrations of zinc, lead and copper in cockles from the Cockle Creek location were always significantly greatest. This is illustrated by the different letters above bars in the graphs. There are indications that, in 1991, significantly greater concentrations of zinc and copper were found in cockles from Kilaben Bay than in those from Crangan Bay.

There was no consistent pattern in the ranking of treatments among locations [Fig. 4B(i-iii)], indicating that sediments from each location did not consistently lead to greater concentrations of lead, zinc or copper.

The accumulation of cadmium was affected most consistently by date with most interactions involving time suggesting greater concentrations in 1991. There were no consistent patterns, leading to the conclusion that no particular treatment or location led to greater concentrations of cadmium in cockles.

This illustrates that, whilst there were small-scale alterations in the ranking of treatments and times within locations, they did not alter the conclusions. Cockles at Cockle Creek always accumulated more lead, zinc and copper than cockles at the other 2 locations and the presence of contaminated sediments did not lead to elevated levels of metals in cockles at the control locations.

Post-hoc analyses of power

The most important non-significant tests were those associated with Treatments. The results of power 
Table 5. Power of tests among treatments. Columns ' 20 ' and ' 40 ' show power for alternative hypotheses of 20 and $40 \%$ increase over control concentrations respectively

\begin{tabular}{|c|c|c|c|c|c|c|c|c|}
\hline & \multicolumn{4}{|c|}{20} & \multicolumn{4}{|c|}{40} \\
\hline & $\mathrm{Zn}$ & $\mathrm{Cd}$ & $\mathrm{Pb}$ & $\mathrm{Cu}$ & $\mathrm{Zn}$ & $\mathrm{Cd}$ & $\mathrm{Pb}$ & $\mathrm{Cu}$ \\
\hline 1989 & 0.63 & 0.82 & 0.75 & 0.72 & 0.99 & 0.99 & 0.99 & 0.99 \\
\hline 1991 & 0.85 & 0.96 & 0.77 & 0.89 & 0.99 & 0.99 & 0.99 & 0.99 \\
\hline
\end{tabular}

analyses (Table 5) for the Treatments effect (years were treated separately) indicated that for an alternative hypothesis of $20 \%$ change, power ranges between 0.63 to 0.96 and for $40 \%$ was 0.99 . This demonstrates that analyses of the effects of treatments were at least as powerful as those for the effects of locations and that the lack of an effect of treatment is not an artifact of the experimental design.

\section{DISCUSSION}

The pilot study indicated that trace metals were not lost from sediments in significant amounts even after considerable disturbance. This result was not unexpected, since laboratory elutriate tests described in Batley (1987) also indicated that the metals in Lake Macquarie sediments were not mobile. Some of the results were unexpected, particularly the differing concentrations in each treatment at the start of the experiment which did not continue to the end of the experiment. A possible explanation is that digging of the sediments disturbed the overall structure of the sediments and may have introduced lumps of less contaminated sediments to the surface of the experimental tubs, where samples were taken. Bioturbation by infauna may have homogenised the sediments during the experiment, leading to more consistent results between treatments, and results which were similar to contaminant levels in undisturbed controls at the start of the experiment.

Importantly, the experimental procedure did not lead either to a decrease in the contaminant levels in disturbed contaminated sediments, either those left at Cockle Creek or those moved to Crangan Bay; or to an increase in contaminant levels in uncontaminated Crangan Bay sediments moved to impacted areas. This allowed the unconfounded conduct of translocation experiments such as those described.

The second series of experiments showed conclusively that zinc and lead were bioaccumulated to significantly greater levels in treatments exposed to relatively elevated water concentrations. Concentrations of metals in sediments had less effect on tissue loads of these metals. It was not possible to determine the rea- son for the lack of any differences for cadmium, even between locations, from these experiments. Possible explanations are that cadmium accumulates over longer time periods, or cockles are able to regulate tissue loads, or that it was present (in both aqueous media and in sediments) in a form unavailable to the cockles, or that the water or sediment concentration gradient was insufficient to produce a significant result. Further work would have to be done to differentiate between these alternatives and the contribution of pore waters (Adams et al. 1992).

The consistency of the trends in the results between 2 trials 2 yr apart adds to the confidence that can be placed in both the procedure and the conclusions. Unpublished data indicate that the same results were obtained for oysters Saccostrea commercialis subjected to the same experimental treatments as described in this paper.

Fairweather (1991) and Peterman (1990) have stressed the potential costs in making environmental decisions on the basis of non-significant results with no consideration of the probability of Type II statistical error. They advocate strongly that the power of nonsignificant tests must be presented when conclusions are drawn from non-significant results (where Power = 1 - Probability of Type II error). Power calculations must, however, be based on an alternative hypothesis which states what is an environmentally/ecologically significant change in the variable being measured. This is often a difficult thing to determine and there are no satisfactory general procedures. Examples of appropriate ways of determining a suitable alternative hypothesis include comparison with legislative standards, or percentage or proportional differences found to be significant in similar studies at another time or place. In this study 2 alternative hypotheses were considered: increases in concentrations from experimental treatments over control concentrations of 20 and $40 \%$. Given that the differences among locations were usually 50 to $700 \%$, the hypothesised alternatives are probably conservative. The power of the tests for treatments with an alternative of $40 \%$ change was nearly 1 . This allows much confidence to be placed in the conclusion that the effects of contaminated sediment on accumulation of metals by cockles are very small.

Correlations between concentration of metals in the water column and in animal tissue is cited by Phillips (1977) as one of the most important attributes of a good indicator, and has been demonstrated for a number of bivalve species (e.g. Klumpp \& Burdon-Jones 1982). Mussels have been shown to be able to accumulate mercury from both dissolved and particulate phases (King \& Davies 1987). McConachie \& Lawrence (1991) found that bivalves accumulated cadmium to much greater levels when they were exposed to contami- 
nated particulates. This study indicates that metals free in the water are responsible for contamination of cockles, but the same result would have been erroneously obtained by correlation with the existing distribution of contaminated sediments. These results underline the importance of manipulative experiments in the explanation of observed patterns. Elucidation of the cause of observed patterns is extremely important in situations such as the one described for Lake Macquarie where potentially costly management decisions may be based on the outcome of the study.

Adams et al. (1992) note that the testing of bulk sediment for trace metals has been shown to be an unreliable measure of bioavailability. The sediments used in the present study were tested for 'bioavailability' using EDTA and other chemical extraction procedures by Batley (1987). He concluded that the majority of zinc and lead in the sediments was present in a form that should be biologically available. This is somewhat in conflict with the studies described in the present paper. Further studies, along the lines of the methods suggested in Adams et al. (1992), would be required to fully assess the toxicology (including bioavailability of metals) of the sediments at Cockle Creek and the role that sediments play in introducing metals into biological systems

There are management implications arising from this study regarding the contaminant load in the water column, sediments and biota. The study suggests that the immediate source of trace metal in cockles is the water column, not the sediments. Further work may, however, be necessary to establish the contribution the sediments are making to concentrations in the water column. Should the sediments be contributing to the contamination of the water column, then removal of the sediments may be justified to reduce water concentrations.

Acknowledgements. I gratefully acknowledge D. Roberts, R Smith, L. de Gail, S. Carter, S. Puckeridge and I. Puckeridge for assistance with field work; Mr G. Henry and Dr R. Macdonald for facilitating the work and comment on the manuscript; Ed Roberts and David Sinclair of Pasminco Metals Sulphide for metal analyses; and Dr S. Kennelly, Di J. Chrystal, Prof. A. J. Underwood and anonymous referees for helpful suggestions on the manuscript.

\section{LITERATURE CITED}

Adams, W. J., Kimerle, R. A., Barnett, J. W. (1992). Sediment quality and aquatic life assessment. Environ. Sci. Technol. 26: $1864-1875$

Batley, G. E. (1987). Heavy metal speciation in waters, sediments and biota from Lake Macquarie, New South Wales. Aust. J. mar. Freshwat. Res. 38: 591-606

Brooks, R. R., Rumsby, M. G. (1965). The biogeochemistry of trace element uptake by some New Zealand bivalves Limnol. Oceanogr. 10: 521-528

Cain, D. J., Luoma, S. N. (1990). Influence of seasonal growth age, and environmental exposure on $\mathrm{Cu}$ and $\mathrm{Ag}$ in a bivalve indicator, Macoma balthica, in San Francisco Bay Mar. Ecol Prog. Ser. 60: 45-55

Connell, J. H. (1961). The influence of interspecific competition and other factors on the distribution of the barnacle Chthamalus stellatus. Ecology 42: 710-723

Dayton, P. K. (1971). Competition, disturbance and community organisation: the provision and subsequent utilisation of space in a rocky intertidal community. Ecol. Monogr. 41 : $351-389$

Fairweather, P. G. (1991). Statistical power and design requirements for environmental monitoring. Aust. J. mar. Freshwat. Res. 42: 555-567

Gray, J. S., Aschan, M., Carr, M. R., Clarke, K. R., Green, R. H., Pearson, T H., Rosenberg, R., Warwick, R. M. (1988). Analysis of community attributes of the benthic macrofauna of Frierfjord/Langesundfjord and in a mesocosm experiment. Mar. Ecol. Prog. Ser. 46: 151-165

Green, R. H. (1979), Sampling design and statistical methods for environmental biologists. Wiley, Chichester

Hurlbert, S. H. (1984). Pseudoreplication and the design of ecological field experiments. Ecol. Monogr. 54: 187-211

King, D. G., Davies, I. M. (1987). Laboratory and field studies of the accumulation of inorganic mercury by the mussel Mytilus edulis (L.). Mar. Pollut. Bull. 18: 40-45

Klumpp, D. W., Burdon-Jones, C. (1982). Investigations of the potential of bivalve molluscs as indicators of heavy metal levels in tropical marine waters. Aust. J. mar. Freshwat. Res. 33: 285-300

Martin, M. (1985). State Mussel Watch: toxics surveillance in California. Mar. Pollut. Bull. 16: 140-146

McConchie, D. M., Lawrence, L. M. (1991). The origin of high cadmium loads in some bivalve molluscs from Shark Bay, Western Australia: a new mechanism for cadmium uptake by filter feeding organisms. Archs environ. Contam. Toxicol. 21: 303-310

Peterman, R. M. (1990). Statistical power analysis can improve fisheries research and management. Can. J. Fish. Aquat. Sci. 47: 2-15

Phillips, D. J. H. (1977). The use of biological indicator organisms to monitor trace metal pollution in marine and estuarine environments - a review. Environ. Pollut. 13: 281-317

Phillips, D. J. H., Yim, W. W. S. (1981). A comparative evaluation of oysters mussels and sediments as indicators of trace metals in Hong Kong waters. Mar. Ecol. Prog. Ser. 6: 285-293

Salomons, W., Forstner, U. (1980). Trace metal analysis in polluted sediments. Il. Evaluation of environmental impact. Environ. Technol. Lett. 1: 506-517

Underwood, A. J. (1981). Techniques of analysis of variance in experimental marine biology and ecology. A. Rev. Oceanogr. mar. Biol. 19: 513-605

Underwood, A.J. (1986). The analysis of competition by field experiments. In: Anderson, D. J., Kikkawa, J. (eds.) Community ecology: pattern and processes. Blackwell Scientific Publs., Melbourne, p. 240-260

Underwood, A. J. (1990). Experiments in ecology and management: their logics, functions and interpretations. Aust. J. Ecol. 15: 365-389

Underwood, A. J., Peterson, C. H. (1988) Towards an ecological framework for investigating pollution. Mar. Ecol. Prog. Ser. 46: $227-234$

Manuscript first received: January 16, 1993

Revised version accepted: August 9, 1993
This article was presented by A. J. Underwood, Sydney, Australia 